\title{
Insect cell lines and baculoviruses as effective biocontrol agents of forest pests
}

\author{
Guido F Caputo ${ }^{*}$, Sardar S Sohi, Sharon V Hooey, Lawrence J Gringorten \\ From 22nd European Society for Animal Cell Technology (ESACT) Meeting on Cell Based Technologies \\ Vienna, Austria. 15-18 May 2011
}

\section{Background}

Canada is a nation of trees. Canadian forests cover $50 \%$ of Canada's land area and represent $10 \%$ of world's forested area. Canada exports more processed forest products than any other country. It is also a host to a variety of forest insects both native and non native that limit the economic, recreational and wildlife habitat use. Our research focuses on initiating insect cell lines, determining nutritional requirements of cells, and developing low cost media for large scale propagation of insect pathogenic viruses as ecologically sound alternatives to chemical pesticides. Cell lines are used for bioassay and strain selection of viruses and bacterial toxins and for production of foreign gene products using baculovirus- and entomopoxvirus expression vectors. They offer a cleaner, viable alternative to insect larvae for producing viral pesticides.

Since 1969, over 150 continuous cell lines have been produced for forest insect pest research at GLFC. This collection represents one of largest single site repository of frozen insect cell lines in the world. Cell lines developed include tissues of the eastern spruce budworm (Choristoneura fumiferana), western spruce budworm (Choristoneura occidentalis), forest tent caterpillar (Malacosoma disstria), tobacco hornworm (Manduca sexta), white-marked tussock moth (Orgyia leucostigma), red-headed pine sawfly (Neodiprion lecontei), gypsy moth (Lymantria dispar), white pine weevel (Pissodes strobi), the tarnished plant bug (Lygus lineolaris) and the ash and privet borer (Tylonotus bimaculatus). These cell lines represent six tissues of origin, namely neonate larvae, pre-pupae, embryos, ovaries, hemocytes, and midgut and four Insect Orders namely Lepidoptera, Hymenoptera, Coleoptera and Hemiptera.

\footnotetext{
* Correspondence: gcaputo@nrcan.gc.ca
Natural Resources Canada, Great Lakes Forestry Centre, Sault Ste. Marie, ON

* Correspondence: gcaputo@nrcan.gc.ca
Natural Resources Canada, Great Lakes Forestry Centre, Sault Ste. Marie, ON P6A2E5 CANADA
}

(C) 2011 Caputo et al; licensee BioMed Central Ltd. This is an open access article distributed under the terms of the Creative Commons Attribution License (http://creativecommons.org/licenses/by/2.0), which permits unrestricted use, distribution, and reproduction in any medium, provided the original work is properly cited.

\section{Lawn assay}

Trees produce numerous compounds with toxic and growth regulating properties to protect themselves against insect attack. We have developed a rapid in vitro agarose lawn assay for testing the toxicity of freezedried ethanolic leaf extracts and secondary compounds. Foliage from sugar maple, trembling aspen and mulberry was assayed for possible insecticidal properties against cells from two lepidopteran defoliators, spruce budworm and fall armyworm. Cells were suspended in buffered agarose and spread in a petri dish. Leaf extracts solubilized in $50-70 \%$ DMSO were applied directly to the cells. Trypan blue staining was used as an indicator of toxicity. Quantitative comparisons were determined by threshold doses that elicited positive responses. Toxicity and validity of the assay were further confirmed by the presence of membrane disruption and cellular lysis. The activity of trembling aspen was markedly enhanced when the $\mathrm{pH}$ was raised from 7 to 10.5 , a level similar 
to that of the larval midgut, but the effect was largely abolished in the presence of gut juice. Analysis of a crude mulberry extract treated with neat gut juice suggested that most of the active material in the lepidopteran leaf diet is either insoluble or precipitated in the larval midgut, while the activity of any solubilized material is suppressed through interaction with gut-juice proteins.

\section{Molecular entomology using insect cell lines}

A spruce budworm midgut cell line, FPMI-CF-203 has been shown to respond to the molting hormone ecdysone, juvenile hormone and other chemicals. Not only was gene expression stimulated in these treated cells, but they allowed for the analysis of house keeping genes or molting gene promoters as well as the study of cell signaling pathways such as protein kinase $\mathrm{C}$ and its targets, steroid hormone and molting gene expression. In addition, GFP tag fused target proteins were readily visible in single living CF-203 cells. They were permissive for the production of active foreign gene proteins using recombinant baculoviruses vector systems. We have observed that while RNA interference (RNAi) technology for the study of gene function does not work well in vivo within the whole insect, CF-203 cells are an invaluable in vitro tool for this function.

\section{Challenges within insect tissue culture discipline}

Developing insect cell lines suitable for a specific application is a very slow and challenging process. Primary cultures started may or may not develop into cell lines. Those that do might take months and the resulting cells may not be suitable for a desired function. Of the 4-6 M insect species, we currently have $800+$ cell lines from 100 species. There are presently no cell lines from exotic or invasive species. Once established, insect cells, like insects, must be fed to be kept alive. Suitable culture medium for the growth of tissues of different insects is currently not available. Large scale production of insect viruses would require the media to be optimal for cell growth as well as for replication of the virus or other control agents. Each cell line/virus combination requires its own unique media composition. Two pressing concerns requiring immediate attention are cross and misidentification contamination of existing cell lines and retiring of key researchers. With few insect cell lines in public collections, private collections are often inaccessible after the principal investigator leaves. Retiring scientist equals lost insect cell cultures.

\section{Future requirements to achieve "cultural immortalization"}

More dedicated researchers developing new lines from different species, routine and aggressive identification, characterization and verification of cells lines employing new molecular techniques and maximizing the potential of insect cells as viable commercial ventures are needed.

Published: 22 November 2011

doi:10.1186/1753-6561-5-S8-P71

Cite this article as: Caputo et al:: Insect cell lines and baculoviruses as effective biocontrol agents of forest pests. BMC Proceedings 2011 5(Suppl 8):P71.
Submit your next manuscript to BioMed Central and take full advantage of:

- Convenient online submission

- Thorough peer review

- No space constraints or color figure charges

- Immediate publication on acceptance

- Inclusion in PubMed, CAS, Scopus and Google Scholar

- Research which is freely available for redistribution

Submit your manuscript at www.biomedcentral.com/submit
C Biomed Central 